\title{
Religiosidade e devoção: caminhos para pensar a cidade
}

\section{Religiousity and devotion: paths to think the city}

\author{
Cairo Mohamad Ibrahim Katrib* \\ Luciane Ribeiro Dias Gonçalves**
}

\begin{abstract}
Resumo: A festa em louvor a Nossa Senhora do Rosário, na cidade de Catalão, localizada na região sudeste do estado de Goiás, é o espaço para a materialização de muitas vozes que contam e recontam muitas histórias dentre elas a da religiosidade e da devoção a uma santa católica. Experimentar a festa, compreender seus sentidos, seu ritmo e o que ela transmite à vida de seus praticantes ea própria cidade não é uma tarefa fácil, pois as experiências concretas da vida dos sujeitos são transformadas, dia a dia, interligando em um tempo fluido, vida, fé, devoção e interesses diversos. O objetivo deste artigo é entender como a história desta devoção se conecta com a história da cidade, percebendo como o culto a Virgem do Rosário e a narrativa que dá sentido as histórias que evidenciam alguns sujeitos como os responsáveis pelo crescimento e desenvolvimento da cidade e da própria comemoração.
\end{abstract}

Palavras-chave: Festividades; religiosidade; cidade

\footnotetext{
* Doutor em História Cultural-UNB. Docente da Faculdade de Educação da Universidade Federal de Uberlândia (UFU), Brasil E-mail: cairomohamad@gmail.com ** Doutora em Educação. Docente da Faculdade de Ciências Integradas do Pontal da Universidade Federal de Uberlândia (UFU), Brasil E-mail: luciane21dias@gmail.com
} 


\begin{abstract}
The feast in praise of Our Lady of the Rosary, in the city of Catalão, located in the southeastern region of the state of Goiás, is the space for the materialization of many voices that tell and recount many stories among them that of religiosity and devotion to a saint Catholic To experience the feast, to understand its senses, its rhythm and what it transmits to the life of its practitioners and the city itself is not an easy task, because the concrete experiences of the life of the subjects are transformed, day by day, interconnecting in a fluid time, Life, faith, devotion and diverse interests. The purpose of this article is to understand how the history of this devotion connects with the history of the city, perceiving how the worship of the Virgin of the Rosary and the narrative gives meaning to the stories that show some subjects as responsible for the growth and development of the city and Own celebration.
\end{abstract}

Keywords: Festivities; religiosity; city

\title{
Espelho festivo: Uma cidade e suas imagens do progresso
}

A história de Catalão-Go, localizada na região sudeste do estado de Goiás, pode ser narrada sob vários aspectos, dentre eles a partir de uma imagem de cidade progressista desbravada por bandeirantes, cujo avanço não veio tão somente a galope como optaram historiadores locais.

A fundação de Catalão, bem como seu desenvolvimento, estiveram atrelados à decadência das atividades auríferas em Minas Gerais e, posteriormente, ao impulso que a agricultura obteve no município, fruto da migração de um número significativo de migrantes que se fixaram na localidade acompanhando as comitivas que se dirigiam para a região do ouro em Goiás.

Pensar a cidade como espaço de sociabilidade permite ao pesquisador compreendê-la como representação da realidade vivida pelos grupos sociais em diferentes momentos da sua história. E ao assim interpretá-la, estabelecer um diálogo com as narrativas dessa história que, por sua diversidade, se desvelam em inúmeras matizes diferenciadas. Nesse sentido, as cidades não são dadas a ler somente pelas relações de produção ali desenroladas e, sim, por todas as formas e práticas sociais, culturais, dentre várias outras que numa inter-relação (re) compõem os mais variados cenários locais. 
Mapa 01: Localização do Município de Catalão-GO. ${ }^{1}$

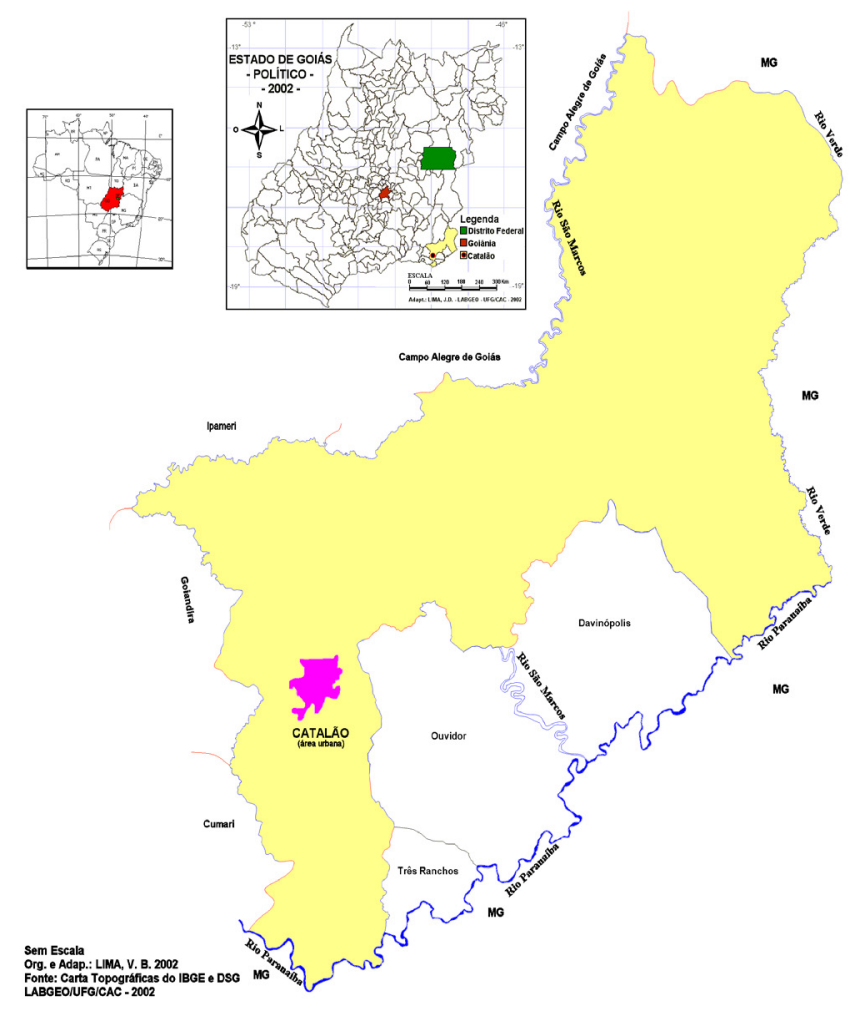

Nesta lógica, enfatizo a necessidade de estabelecer um diálogo com a história já produzida sobre Catalão-GO, de modo que para entender sua trajetória seja necessário levar em cosideração os anônimos sociais e aqueles que foram materializados pelo história oficial, ambos como sujeitos sociais de seu tempo, partícipes da cultura popular local.

Nesse compasso, as obras dos historiadores locais, servem-nos de suporte para pensar todo esse processo histórico que envolve a história de Catalão, principalmente porque ambos levam em consideração as descrições feitas por Saint-Hilaire ${ }^{2}$, atribuindo o papel de herói ou de desbravador da região estudada ao bandeirante Bartolomeu Bueno da Silva Filho "o Anhanguera".

Catalão surge, nesse contexto, supostamente da fixação de membros das expedições comandadas por Anhanguera, que ultrapassaram os limites das Minas Gerais através da transposição das águas do rio Paranaíba (vide Mapa 1) $\mathrm{e}$, adiante, às margens de um córrego, quando parte da comitiva se fixou fazendo do lugar ponto de apoio aos passantes que ali pernoitavam, organizavam sua frota e suas provisões e seguiam viagem sertão adentro.

Catalão, desde o início de sua ocupação territorial, e devido a sua localização privilegiada, se configurou em importante referencial aos viajantes, sendo marco de entrada em Goiás para os que vinham do sudeste, o que fez com que, na segunda metade dos anos de 1700, se transformasse em importante 
entreposto comercial, justamente pelo fato de ser lugar de passagem obrigatório para os transeuntes que se direcionavam para as reservas auríferas de Goiás.

Nesse viés, Catalão pode até ter se originado das Entradas e Bandeiras, justamente em virtude da fragmentação do ciclo do ouro em Minas Gerais. Porém, seu desenvolvimento se deveu em função das atividades comerciais ali consolidadas a partir dos anos de 1700 até ser reconhecido como município em 1859.

Já entre os séculos XIX e XX o número de pessoas oriundas das Minas Gerais no município aumentou substancialmente, e muitas delas se estabeleceram como fazendeiros em Catalão e, devido a essa atividade, trouxeram consigo grande parte da mão de obra a ser empregada em suas terras, principalmente remanescente da escravidão, com a finalidade de trabalhar na produção de café na região.

Os registros memorialisticos locais nos levam a perceber que muitos fazendeiros entravam em Goiás por dois pontos principais: uns atravessavam o Rio Paranaíba chegando às terras do município; outros vinham de diferentes cidades de Minas Gerais, passando por Paracatu-MG, até chegar a Catalão.

Nessa vertente, supostamente é possível indicar que a proximidade de Catalão com Minas Gerais facilitou suprir a falta de mão de obra para o trabalho nas lavouras. O maior número de trabalhadores de descendência negra vinha de Paracatu, fazendo com que o contingente de afrodescendentes em Catalão fosse bastante considerável entre os séculos XVIII e XIX.

Ao relacionarmos as narrativas dos historiadores locais acerca da ocupação profissional dos congadeiros, ou seja, dos brincantes da festa em louvor a Virgem do Rosário, em Catalão, fica nítida a diversificação dos oficios desses trabalhadores que atuavam tanto no campo quanto na cidade ${ }^{3}$. O que se presume é que com o crescimento local, muito negros migraram para o município e, com o caminhar das décadas, passaram a executar atividades diversificadas como de pedreiros, carpinteiros, domésticas, empregados das charqueadas, dentre outras funções.

Além das mudanças observadas no do do trabalho do negro, percebese as transformações culturais significativas no município. Ao se fixarem na região, tanto os brancos quanto os negros não trouxeram apenas as esperanças de um futuro melhor, trouxeram hábitos, costumes, práticas e saberes que, aos poucos, se polvilharam e foram transmitidos, recriados, dando sentido cultural ao lugar; dentre essas manifestações destacam-se as comemorações em louvor a Nossa Senhora do Rosário, realizadas com muita dança, batuque e cantoria, através do Congado, uma prática cultural que ritualiza e atualiza a coroação dos reis negros no Brasil escravista.

Nessa lógica, tecer uma reflexão acerca da história de Catalão, só se torna envolvente se a vincularmos à compreensão da importância que os festejos em louvor a Nossa Senhora do Rosário tem na recriação das práticas culturais 
locais e na efetivação dessa comemoração como marca de sociabilidade e cultura do lugar. É nesse sentido que percebemos que a história da cidade se entrelaça à história da própria Festa e vice-versa.

A cidade é tida, então, como importante espaço de concretização de de sociabilidades porque "ela comporta atores, relações sociais, personagens, grupos, classes, práticas de interação e de oposição, ritos e festas, comportamentos e hábitos". ${ }^{4}$ Sendo assim, as histórias oficializadas ou as pessoas que deram vida a essas narrativas ajudam-nos a recompor o mosaico de possibilidades interpretativas de compreenção dessa dada realidade que movimenta a história local e a da própria religiosidade em torno da devoção a Santa do Rosário, pois essa história linear e conectada ao ritmo harmônico da sociedade é a base que sustenta a reflexão aqui pretendida. É notório que esses sujeitos não serviram apenas para aumentar as estatísticas sobre a população local. Eles trouxeram na bagagem, muito mais que pertences. Trouxeram sonhos, saberes, culturas. Histórias de vida; narrativas que hoje nos ajudam a desvelar a(s) história(s) das terras de/do Catalão.

Todavia, mesmo considerando os muitos processos de desenvolvimento e interdependência de fatores desencadeados ao longo de sua história, como seu vigor agrícola e comercial, a sua posição geográfica associada à passagem da ferrovia e, posteriormente, da BR-050, a descoberta das jazidas minerais, dentre outros aspectos, a história de Catalão nos revela outras narrativas. Se o progresso de Catalão veio no trote ligeiro do desenvolvimento do campo, acompanhando o apito da Maria Fumaça, percorrendo os trilhos da estrada de ferro guiado pelo cheiro do minério, pelo alvorecer do conhecimento acadêmico, muitos personagens anônimos também entram em cena enquanto sujeitos sociais de seu tempo, vivendo e tecendo tramas, enrredos, jogos de interesses em prol ou da visibilidade social e política do fazer-se visto.

Foram pelos trilhos ou pelas picadas no cerrado que vieram muitas transformações; muitas histórias se concretizaram como versões capazes de alinhavar as memórias passadas às memórias recentes. Nesse sentido, refletindo sobre essas possibilidades, o caminho trilhado pela história da cidade, em especial pelas lentes da história local se volta para o fervilhar do progresso, das narrativas sangrentas que, também, compõem o ritmo da história da cidade.

[...] vemos emergir de todas as narrativas citadas, a violência como marca explicativa do lugar. Os grupos sociais que adquirem relevância nas histórias são sempre aqueles ligados às tramas de morte, sangue e vinganças. [...] A violência se traduziria como valentia, força condutora a um novo tempo. Por outro lado, surge em conjunto a esse discurso da violência, um outro que dá a Catalão mais uma insígnia: a de cidade progressista e destinada a ser "orgulho do Brasil". ${ }^{5}$ 
Os diversos enredos mostram que tais representações se constituem de múltiplas falas, que felizmente não se cristalizaram enquanto narrativas únicas para contar a história de uma cidade promissora e ancorada ao ritmo do desenvolvimento e do progresso nacional, como descritas em muitos registros oficiais sobre Catalão. Outras narrativas paralelas ou esculpidas no avesso da memória a estas se consolidaram como parte da história de Catalão e foram transmitidas pela oralidade.

\section{Uma história reescrita por sangue, chumbro fé e festa}

São essas outras falas desse avesso que nos conduzem a reler os registros escritos sobre Catalão como caminho formado por outras histórias. Histórias de vidas de muitos sujeitos. Protagonistas anônimos que construíram e presenciaram outros momentos de uma cidade dos mandos e desmandos dos coronéis; das rixas políticas e também de múltipla efervescência religiosa em que a fé e devoção a Santa do Rosário parecia, para muitos, a única saída para reverter a imagem de uma Catalão violenta para a de uma cidade ordeira e de gente de paz.

Coincidência ou não, no mesmo ano em que a Festa retoma o seu lugar na cidade, com a doação de um terreno para se construir uma nova Igreja, crimes bárbaros ocorreram, sinalizando que a violência ainda estava presente em Catalão.A morte de Antero da Costa Carvalho, ocorrido em 30 de agosto de 1936, morto de forma brutal, acusado de um crime ainda hoje não solucionado pela justiça de Goiás é um marco histórico significativo que utilizo para referendar o aumento da devoção a Nossa Senhora do rosário na cidade ( Antero foi morto após ser torturado a golpes de facada, ser arrastado pelas ruas da cidade, puxado por cavalos, ter suas unhas e dentes arrancados à força e ser espancado por golpes de chave de fenda, alicate, objetos pontiagudos ${ }^{6}$. Antero hoje é considerado "santo" pela população, mesmo que não reconhecido pela Igreja. No local onde faleceu, foi erigida uma pequena capela que é repleta de ex-votos. Seu túmulo também recebe durante todo ano uma peregrinação constante de fiéis que vão ali em busca de bênçãos ou para pagar suas promessas.

Essa relação é estabelecida na comparação dos fragmentos das histórias oficializadas nas obras memorialísticas em momentos isolados, descortinando a Catalão da devoção e a dos mandos e desmandos dos coronéis locais. É nítido ainda, nas obras dos memorialistas a percepção da construção de uma imagem da cidade de Catalão como expressão da religiosidade e da devoção como tentativa de silenciar a violência, referendando à cidade o título de terra do Congado, pela devoção a Virgem do Rosário, que desde o início era conclamada a propagar a paz da cidade, cuja história necessitava ser reescrita, não com sangue e chumbo, mas sim com fé e festa.

A história da cidade de Catalão-GO, ao percorrer outros caminhos, como 
o da fé e da devoção, encontra nos devotos do Rosário- homens e mulheres de cor e de fé - outros narradores que reescrevem a história da cidade a partir de suas vivências. E ao remontarem às lembranças do passado e recompô-las em gestos de religiosidade, dão novos sentidos à trajetória do lugar, abrindo novas trilhas e possibilidades para se (re) contar a história de Catalão.

Diante disso, nos reencontros com o passado, os sujeitos materializam no presente novas vozes e, juntamente com as lágrimas e os sorrisos de tantas vivências compartilhadas, as pessoas (re) contam histórias, dando a elas sentidos plurais. São esses sentidos que nos levam, aqui, a pensar a cidade como o lugar da festa, já que muitos sujeitos (re) vivem esse espaço e a comemoração, reelaborando, promovendo e presentificando o seu (re) encontro com muitas histórias esquecidas que voltam a pulsar, mantendo vivas as memórias dessa devoção ao Rosário em Catalão.

Nessa trajetória, a história do município registrada pelos historiadores locais pode percorrer vários caminhos sendo eles os dos mandos e desmandos políticos, os das riquezas minerais, da pujança agropecuária e também da devoção. Nesse sentido, essas narrativas podiam ser recontadas, principalmente se levasse em consideração outras histórias como a das festividades do Rosário, mas agora sob a perspectiva de quem efetivamente faz a festa acontecer: os congadeiros.

Dessa forma, ao dialogar com a história de Catalão tendo como ponto de partida o início dos festejos em louvor a Nossa Senhora do Rosário no município, é possivel afirmar que seu desenvolvimento e crescimento socioeconômico esteve atrelado a comemoração. Essa possibilidade de reflexão nos permite compreender a cidade como sendo o lugar da festa, porque ao longo de sua realização, a festividade foi tomando a forma que hoje garante a ela a posição de comemoração festivo-devocional mais importante do Estado de Goiás, patrimônio cultural popular e importante atrativo turístico que, durante os dez dias de festividades, eleva a sua visibilidade, projetando-se nos meios de comunicação nacional e, com isso, atraindo um número expressivo de turistas para participar dessa comemoração.

Catalão oficialmente elegeu Nossa Senhora do Rosário como a padroeira da cidade em 1973. ${ }^{7}$ Essa oficialização não se deu de forma aleatória. A cidade desde sua fundação já era conhecida pela realização dos festejos do Rosário. O poder público local percebendo essa característica marcante de população festeira procurou paulatinamente inserir a festa do Congado de Catalão no roteiro turístico do Estado.

Contudo, desde 1830, essa manifestação cultural foi assumindo contornos diversos até ganhar maior expressividade e visibilidade na região, se transformando na mais importante Festa de Santo padroeiro do estado de Goiás e, possivelmente, a maior em número de congadeiros do país, constatação oriunda da pesquisa feita sobre esse tipo de comemoração existente pelo 
interior do Brasil.

Compreender qual é o papel assumido pelos narradores e construtores dos enredos que circundam a história de Catalão-GO, em relação à comemoração é o fio condutor que nos propicia a concretização de um entendimento dessa dinâmica que envolve a cidade e a festividade.

Dessa maneira, a cidade e suas narrativas devem ser entendidas como constituintes de um espaço de vivência, sensorial e intelectual ${ }^{8}$ dos grupos sociais que as difundiram. Assim, a cidade pode ser (re) lida justamente pelas frestas dessas muitas histórias que dão identidade própria ao lugar, posto que a identidade não é o resultado fechado de heranças culturais, mas a produção contínua e dolorida de criações diárias, inseridas no jogo social. ${ }^{9}$

É na cidade que as experiências e os muitos sujeitos compartilham suas histórias e o historiador não deve perder de vista que elas são os espaços (social, político, físico) por isso, sempre lugares praticados, que reconstroem a sua lógica e estabelecem suas configurações dentro de uma lógica própria, porém influenciada pelas ações intencionais desses muitos sujeitos.

A cidade está em constante movimento. Por isso, repensar as muitas leituras sobre a sua história é crucial para o diálogo aqui pretendido. Nesse contexto, é possível perceber que a travessia da memória para a escrita se dá de forma fluida, pela qual o historiador (re) compõe o enredo, reelabora a fala de seus narradores, (re) elege os fatos marcantes e as histórias a serem veiculadas, as materializa na forma de escrita, dissemina esses enredos e imprime a essas narrativas o estatuto de verdade.

Por outro lado, questionamentos diversos também colocam em xeque a veracidade dessa história dita oficial, pois a escrita da história de um dado lugar é uma viagem de múltiplos caminhos e, ao longo desse percurso, a capacidade inventiva e/ou representativa do narrador é que coordena a lógica real da escrita, se materializando na história oficial do lugar ou nas muitas versões criadas, próximas daquilo que se edificou como a história do lugar. ${ }^{10}$

No caso específico de Catalão é perceptivel que mesmo os historiadores locais direcionando as narrativas e dando a elas oficialidade, suas histórias abrem brechas para percebermos outras narrativas. Como se fossem "molduras sobre um determinado lugar e criada através das palavras é instituída a partir de imagens que projetamos sobre esses espaços, os quais internalizamos na memória", assim estabelecendo vínculos com elas. ${ }^{11}$

Os historiadores locais, são pessoas eleitas para narrar histórias, dandolhes um caráter de veracidade, de oficialidade, é quem lembra e traz à tona as lembranças vividas, claro que à sua maneira, a partir daquilo que ouviu contar, elegendo a versão que deseja registrar. Nessa perspectiva, essas narrativas servem-nos de ponto de partida para pensarmos outras versões possíveis e, nesse sentido, a memória é fundamental na recomposição das diversas tramas estabelecidas. 
Entender essa relação entre as narrativas e a construção de seus sentidos, oficializando uma dada história é decifrar essas intenções da escrita através da (re) leitura dos registros. ${ }^{12}$ Assim, ler, escrever, narrar, são exercícios de (re) elaboração que desafiam o tempo, as memórias, podendo causar a reviravolta de muitas histórias. Dentro dessa lógica, o exercício da memória propicia questionamentos sobre a credibilidade das narrativas que engendram os registros das histórias eleitas como verdadeiras, apontando outras possibilidades de interpretação que não aquelas factualmente produzidas e reproduzidas ao longo dos anos.

Portanto, a cidade enquanto o lugar, por excelência, da efetivação de muitas histórias, elege espaços e sujeitos para a concretização das mesmas, evidencia os atores que serão os protagonistas e dão a eles a voz que direcionará a condução do novelo com o qual a história será tecida.

Os festejos do Rosário em Catalão-GO, ao longo dos seus mais de 140 anos de realização, foram assumindo contornos diversos, de acordo com os interesses dos sujeitos que passaram a incentivá-los ou em tê-los como marca fundante de suas vidas.

A Festa materializa-se como o lugar onde os sujeitos podem tanto usufruir dela como espaço estrategicamente pensado para efetivação de táticas de projeção e visibilidade social e política, como também concebê-la como cenário para corporificação da sua fé, dando vazão aos seus desejos e expressando seus mais íntimos sentimentos de pertença, revivendo sua ancestralidade e festejando a vida. Entretanto, todas essas possibilidades não se limitam ao espaço oficialmente demarcado para acontecer as festividades.

A história local nos permite confrontar fatos e fragmentos da história da cidade e da festa que foram consagradas como as oficiais, elegendo alguns acontecimentos como fio condutor dessa análise, dentre elas a consolidação dos festejos e da religiosidade em torno da Virgem do Rosário em Catalão. Essa festividade acontece, com base nos registros oficiais desde os remotos anos de 1830, e as primeiras comemorações foram realizadas nas fazendas da região, onde se rezava o terço e realizavam-se as comilanças, os bailes e o congado.

$O$ congado era praticado pelos negros que trabalhavam nas fazendas em Catalão e que no dia de louvar a Santa, se juntavam à população local para homenageá-la. Ela destaca que a benevolência dos fazendeiros creditava aos negros o direito de participação nas comemorações, pois naquele momento não existiam diferenças raciais. Vale ressaltar que ao celebrar a Santa os negros não estavam exaltando tão somente o catolicismo pregado nas fazendas, mas também seus orixás, já que ritualizavam e atualizavam costumes trazidos da África, reelaborando os seus cultos ancestrais.

Esses fatos nos ajudam a recompor esse cenário em que a festividade e a devoçãose imprime como marca cultural tendo a cidade como seu grande palco. No período de 1860 até por volta de 1930, aconteciam em épocas esporádicas, 
coincidindo com as datas comemorativas como abolição da escravatura, dia do Santíssimo Rosário, dia de Santa Efigênia, São Benedito e Nossa Senhora. Posteriormente as autoridades locais instituíram as duas primeiras semanas de outubro como o período para louvar a Virgem do Rosário na cidade, coincidindo com o da Padroeira do Brasil - Nossa Senhora Aparecida.

A realização das comemorações ocorria em várias fazendas do município. No entanto, à medida que Catalão foi ganhando aspectos de cidade mais importante da região, seus incentivadores para lá se mudaram, levando consigo as festividades em devoção a Nossa Senhora do Rosário, nos moldes de sua realização no campo e que, aos poucos, foi ganhando outros contornos para atender os interesses dos moradores.

No diálogo mantido com a história dos festejos pelos memorialistas, e perceptivel verificar nas entrelinhas que as dificuldades encontradas pelos devotos, principalmente em relação à participação dos negros no culto a Nossa Senhora do Rosário foram muitas. Inclusive, destacaram que muitos padres não aceitavam essas práticas festivas, mesmo assim, os brancos mais solícitos e também devotos do Santíssimo Rosário convenceram os clérigos a permitirem o culto à Santa pelos negros.

$\mathrm{O}$ incentivo dado à festa não partia da Igreja que, muitas vezes, tentou acabar com a comemoração. Foi a devoção popular que fez com que ela se firmasse em Catalão como marco cultural local. Aproveitando disso, tanto a Igreja quanto as pessoas de posse ou aqueles com pretensões políticas, viam na manutenção da comemoração as possibilidades de firmar o seu prestígio social e, no caso da igreja, lucrar com os donativos e rendas oriundos dessa festividade, dentre outros aspectos.

Não se pode deixar de frisar que a pretensa boa vontade dos brancos em reverter a proibição por parte da Igreja Católica em permitir as festas aos Santos de devoção na cidade, como também a luta pela permissão à participação dos negros nos festejos em Catalão se dava mais no âmbito da cidade, pois no contexto rural os clérigos pouco interferiam. Isso se deve ao fato de, no século XIX, ter se iniciado no interior da Igreja Católica, por parte dos agentes ultramontanos, um movimento de proibição de cultos e festejos aos santos de devoção popular, inclusive vários deles foram retirados das igrejas, na tentativa de evitar, no interior das mesmas, o que chamavam de adoração exacerbada dessa hagiografia devocional.

Os rituais do catolicismo popular eram festivos e profanos e as festas de santo, que acompanhavam esse calendário festivo-devocional, toleradas pelos padres; pouco valor tinham para a ortodoxia católica apostólica romana, visto que valorizavam muito mais as práticas cristãs de generosidade e solidariedade, promovendo a comensalidade, as danças, a música e os autos e festas de santo, não expressando os interesses da Santa Madre Igreja. ${ }^{13}$

Contudo, no interior do país, os jogos de interesses que alicerçavam 
as relações entre a Igreja e as elites locais eram grandes. Em virtude disso, algumas práticas devocionais como as festas, mesmo condenadas aos olhos da igreja, eram praticadas sem tantos constrangimentos, salvo quando um religioso resolvia utilizar algum mecanismo mais brusco de manutenção dos princípios clericais.

O Congado é uma festa que acontece em sua maioria associada às celebrações em homenagem aos santos de devoção negra como Nossa Senhora do Rosário, Santa Efigênia, São Benedito, Santo Eslebão, dentre outros. O que faz dela uma prática cultural popular bastante eclética.

Os relatos dos folcloristas destacam que o Congado se desenvolveu pelo Brasil, desde o inicio da colonização, "partindo das regiões litorâneas para o interior, acompanhando o processo de escravidão e da exploração econômica do território brasileiro". ${ }^{14}$ Muitos folcloristas realizaram densas pesquisas detalhando e mapeando esse tipo de prática da cultura popular. O Reisado, as festas de coroação dos reis negros, as marujadas e o Congado, dentre uma série de outras práticas, foram descritas como "meras encenações exóticas, fruto de uma deturpação cultural desencadeada a partir da apropriação cultural européia". ${ }^{15}$

O congado representa, nessa lógica, em cada lugar em que é praticado, um sentido próprio, podendo simbolizar a luta religiosa travada na Idade Média entre cristãos e mouros ou refletir sobre os conflitos para o fim do processo de escravidão. No caso da devoção ao rosário e, consequentemente, à Nossa Senhora, esta prática se difundiu através do processo de catequese iniciado na África, quando de sua ocupação pelos portugueses que incentivaram o culto ao rosário. Com o processo de escravidão e a vinda dos africanos para o Brasil, a aproximação desses sujeitos com o catolicismo praticado nas fazendas do país propiciou unir reza e festa em prol de uma devoção comum entre brancos e negros, o que acabou por promover o desenrolar de um catolicismo que nasceu apostólico romano e se recriou dentro de um modelo rústico de catolicismo rural, ganhando cada vez mais adeptos. ${ }^{16}$

Associado à devoção aos santos católicos, os africanos, no Brasil, introduziram nos festejos religiosos elementos representativos da sua cultura, como a coroação de reis negros, as danças, cuja encenação remonta às batalhas travadas entre as tribos rivais, imprimindo nessa prática um referencial cultural pautado na sua ancestralidade que, ao mesmo tempo, pudesse ser realizada sem levantar grandes suspeitas.

O congado se difundiu com características próprias pelo Brasil colonial, e foi absorvendo as várias maneiras de cultuar os santos protetores, recriando formas específicas de celebração. Os negros reafirmaram sua identidade cultural, ao utilizar os elementos de sua devoção às próprias práticas culturais e religiosas europeizantes na realização dessas festividades pelo interior do Brasil. ${ }^{17}$ 
O congado mesmo tendo um lastro luso-afro-brasileiro, já apresenta na própria devoção à Virgem do Rosário uma miscelânea de cultos e formas recriados nas diferentes devoções. Assim, não há como definir as origens dessa prática, a sua organização, não seguindo unicamente nenhum modelo imposto, seja pela igreja ou pelos grupos sociais no poder.

Fica evidente que os festejos aos santos padroeiros, em sua maioria, estiveram relacionados aos relatos folclóricos na forma de autos populares, sendo que o Congado dentro de todas as suas ramificações (Reisado, Embaixadas, Marujadas, dentre tantas outras) não foi percebido como integrado à dinamicidade cultural, com especificidades e semelhanças peculiares da cultura das várias regiões brasileiras.

Essa visão de padronização cultural contribuiu para que muitas práticas culturais como o congado passassem a ser vistas como mera encenação vazia, fruto das tentativas de enquadramento cultural do país no modelo evolutivo das sociedades europeias ditas civilizadas. Isso nos faz questionar que essa unificação de sentidos culturais e a percepção de Brasil homogêneo frente à pluralidade cultural efervescente descrita pelos próprios folcloristas ao relatarem o cotidiano do interior do país através de festas e rezas. ${ }^{18}$ Práticas culturais populares como o Congado sempre foram realizadas com muitas danças pelos negros desde a época da escravatura, funcionando como mecanismos de resistência significativos contra a escravidão e a imposição cultural europeia difundida pelo colonizador, sendo também um "hábil meio de diminuir tensões". ${ }^{19}$

Numa outra perspectiva podemos destacar que exixte uma forte influência africana na cultura popular brasileira, principalmente no que se refere às práticas culturais festivas, que reverenciam os reis negros, como o Congado, resultado do encontro cultural da sociedade brasileira. ${ }^{20}$

Em Catalão, no início dos anos de 1900, um padre da época, na tentativa de fazer cumprir o que a Santa Madre Igreja determinava, em relação a esse tipo de prática devocional, trancou com correntes e cadeados a igreja onde era costume acontecer os festejos em devoção a Senhora do Rosário, impedindo, principalmente, que os negros adentrassem o templo para cantar e louvar a Santa.

No dia do festejo o padre viajou levando consigo a chave da igreja na tentativa de realmente impedir que a festa acontecesse. Porém, o cadeado foi arrombado, a igreja aberta e os fazendeiros providenciaram um rezador para que comandasse a parte litúrgica, e a festa assim se realizou.

Por outro lado, há de se levar em consideração que existiam também aqueles clérigos menos radicais, que preferiam negociar o formato da festa a ser realizada, pois a permissão dos festejos significava manter os laços de sociabilidade com os fazendeiros e a população local, já que quem mantinha as regalias das paróquias com donativos e doações de terras e outras ajudas 
era a população, em especial os fazendeiros mais afortunados, que estavam à frente da realização da comemoração no município. Mesmo assim, isso não impedia, por completo, os conflitos e confrontos entre Igreja e a sociedade quanto o assunto era a forma como a Festa era organizada pelos fazendeiros daquela que a Igreja tentava implementar.

É válido frisar que a concepção negativa com que os padres recebiam a religiosidade dos negros se ancorava no autoritarismo do catolicismo romano frente às práticas culturais populares, combatidas a partir da segunda metade do século XIX. Nessa época, o pontificado de Pio IX (1846-1878) movimentou o cenário religioso no país, e se de início parecia liberalizante, tomou, posteriormente, outros rumos, se apegando a uma visão mais conservadora em relação à participação dos eclesiásticos na vida pública da sociedade, seguindo o que rezava a encíclica Quanta Cura (1864), estabelecida pelo Concílio do Vaticano I, que definiu a infalibilidade pontifícia. Pretendiam combater os males extremos, como o liberalismo e o Padroado. ${ }^{21}$

Esta postura refletia a necessidade de uma reforma no que se refere ao posicionamento da igreja católica no que diz respeito à vida religiosa dos fiéis e à participação desta igreja na sociedade.

Dessa maneira:

No final do século XIX, entretanto, as devoções que possuíam uma larga expressão popular, como a de São Benedito e a do Divino Espírito Santo, a de Nossa Senhora do Rosário, a de Santa Efigênia, a de Santo Elesbão e a dos Reis Magos começaram a ser desqualificadas pelos agentes ultramontanos. Discretamente as imagens eram retiradas dos altares centrais e alojadas em capelinhas. O mesmo se deu com as devoções brancas, de fortes raízes populares - como o culto ao Bom Jesus Sofredor, expresso nas diferentes figurações do Bom Jesus da Cana Verde, da Lapa, dos Perdões, do Senhor dos Passos, do Bom Fim, do Senhor Morto - entre outras devoções. Era aos santuários que os devotos acorriam em romarias para cumprir promessas, deixar seus ex-votos e fazer pedidos. As diversas irmandades leigas ligadas às devoções incumbiamse de promover o culto por meio de festas e de procissões populares. As imagens do milagroso Bom Jesus iam sendo substituídas pela divulgação de outra, ligada ao culto do Sagrado Coração de Jesus, promovida especialmente pelos padres jesuítas através de associações, agora ultramontanas, como o Apostolado da Oração. Como expressão dessa nova devoção, começaram a surgir as suas primeiras igrejas, aflorando a luta subjacente entre as devoções romanizadas trazidas da Europa e as antigas formas típicas de um 
catolicismo luso-brasileiro. ${ }^{22}$

Levando em consideração a reflexão da historiadora é pertinente afirmar que o catolicismo no Brasil passa por uma readequação na sua forma de perceber os fiéis e os cultos por eles praticados. A Igreja pretendia, a partir daí, acompanhar mais de perto a ação dos leigos diminuindo o poder de organização religiosa dos mesmos. Para tanto, tencionava-se diminuir as carências sacerdotais implementando a vinda de ordens estrangeiras, principalmente para se instalarem no interior do país, suprindo as deficiências nacionais, dando também autonomia às paróquias, já que estas se desvincularam do Estado, necessitando, por isso, alcançar mais fiéis para aumentar as doações e os dízimos que dariam sustentação à vida paroquial. Apesar disso, o catolicismo popular permaneceu vivo em amplas camadas da população.

É este fato que mantinha presente na vida da sociedade, a devoção e as diversas práticas de aproximação com o sagrado, construídas pelos grupos sociais à medida que a fé e a religiosidade afloravam como marca identitária de muitos brasileiros. Com isso, outras formas de religiosidade foram reelaboradas pelas camadas populares, que não se curvaram frente à imposição católica, continuando a praticar e exercer sua fé por meio de diferentes mecanismos criados para mediar a sua interação com o sagrado.

Em Catalão, conforme se percebe houve uma tentativa de estabelecer parâmetros para as práticas de devoção e da fé católica que eram controversas, pois se de um lado a Igreja atendia ao que rezava as determinações do Vaticano, por outro, tinha que arcar com o ônus da perda das regalias mantidas pelo poder político local. Por isso, a manutenção ou a imposição de uma identidade homogeneizante católica para todo o país não seguiu adiante e, em Catalão, isso não foi diferente.

Portanto, a igreja local, após inúmeras tentativas de impedir a realização dos festejos, percebeu que as estratégias de proibição não funcionavam, uma vez que ela perdia fiéis e se enfraquecia, pois as pessoas continuavam a realizar os festejos sem a presença dos clérigos e com isso um catolicismo popular e festivo se consolidava em Catalão, conforme também acontecia pelo restante do país.

Em Catalão, grande parte da população seguia os preceitos ditados pela Igreja Católica, mas em relação às formas de culto e adoração desenvolveram as suas próprias maneiras de festar e celebrar sua devoção, especialmente pelas premissas do catolicismo rural da região. As práticas culturais, que mesclavam em sua realização os saberes da cultura negra, eram sempre celebradas com muita festa, e embora a Igreja condenasse o devotamento exacerbado, muitos fiéis incorporavam essas manifestações às suas práticas cotidianas.

É visível que a sociedade local se dividiu entre aceitar um catolicismo brando, que permitia a cultura negra se fazer presente nos ritos católicos locais; 
presentes principalmente, nas comemorações em louvor a Nossa Senhora do Rosário, ou em seguir rigorosamente os ensinamentos da Santa Madre Igreja. A primeira opção foi aquela que vigorou. Fica claro também que o que mais interessava não eram os ditames da Igreja e sim, a importância que o participar e o incentivar essa prática cultural tinha para alguns membros da sociedade, pois através da festa se faziam vistos e mantinham seu poder e sua projeção política e social. Vejamos:

A festa modificou-se bastante, principalmente no que se refere a parte ritual, mas adquiriu grandes proporções se transformando numa romaria que enche a cidade de barraqueiros e romeiros, na primeira quinzena do mês de outubro. É uma grande tradição da cidade. É um importante folclore que possuímos com suas tradicionais congadas, que atraem parque de diversões, circos, jogos, grande número de barraqueiros, com mercadorias de todos os tipos e para todos os gostos, bebidas e uma grande variedade de frutas e comestíveis. Tudo aí se encontra por ocasião da festa. Qualquer artigo ou mercadoria por mais raros que sejam, basta saber, para encontrá-los na confusão desordenada dos barraqueiros, onde está construída a Igreja desta Santa, padroeira das Congadas. Ocupando toda a rua que fica em frente à igreja, constróise o Ranchão, coberto de palha de buriti, cercado de pau a pique, que é a barraca da festa, com tablado, onde são feitos leilões durante os 10 dias de festividades. O Ranchão todo cheio de mesinhas e cadeiras, muito bem enfeitado e iluminado, é o centro de atração, onde os festeiros com sua grande turma de auxiliares movimentam as atividades, para se angariar donativos. Uma animada orquestra e alto falante enchem de sons o ambiente já poluído com o barulho dos muitos comerciantes, que numa disputa frenética, jogam pelos ares, seus anúncios e propagandas. Nos dias de festa uma verdadeira multidão humanaburbuorinha em torno do largo. Grande parte dos comerciantes da cidade também ali arma suas barracas, no intuito de maiores vendas. Os barraqueiros alugam da prefeitura o terreno onde se localiza, o que proporciona ao poder municipal grandes lucros. Antigamente este terreno alugado era em frente das residências, ficando vago o centro das ruas, e os moradores é que recebiam satisfeitos, boas quantias. ${ }^{23}$

As impressões de Campos permitem ter uma visão da espacialidade 
dessa comemoração e sua inserção no contexto urbano agregando novos valores ao rezar e ao festar na cidade. Suas narrativas privilegiam os fazendeiros tradicionais como incentivadores dos festejos em torno de Nossa Senhora do Rosário em Catalão-GO.

Nesse contexto, alguns personagens foram eleitos pelos historiadores locais como os principais, como sendo os maiores incentivadores dos festejos em Catalão. São eles, os fazendeiros: Coronel João de Cerqueira Netto; o Coronel João Eustáquio de Macedo e Irineu Francisco do Nascimento Pereira, ambos parentes ou amigos próximos da sua família. Eram sempre os festeiros - pessoas responsáveis por organizar a parte festivo-devocional das comemorações em louvor a Nossa Senhora do Rosário. Eles se revezavam ano a ano nessa função acompanhados de outros membros da família. Eram eles também os representantes políticos do lugar, que detinham o poder e mandavam no município, eram os responsáveis pela segurança e pela ordem, posto que a maioria ocupou cargos significativos nas diferentes esferas do poder público, o que reforça a hipótese de uso da festa como importante vitrine de projeção social e política.

A própria memorialista Maria das Dores Campos foi festeira por duas vezes. Uma delas com apenas cinco anos, juntamente com Célio Netto Paranhos, o festeiro. Os festeiros, como ela descreve, se vestiam de rei e rainha e eram carregados pelos negros, conduzindo a coroa de Nossa Senhora numa bonita bandeja de prata. Toda a despesa da festa era bancada pelos festeiros. Os muitos contornos dados à Festa funcionavam como estratégia de projeção social e todo incentivo às comemorações girava em torno desse aspecto. Dessa forma, os mecanismos de atuação desses fazendeiros ganhavam forma à medida que estabeleciam uma rede de organização capaz de atender seus interesses.

Sendo assim, a comida servida aos negros e à população, que era de responsabilidade dos fazendeiros que ocupavam a função de festeiros sociais, estampava a imagem de fartura e riqueza do fazendeiro. Segundo Campos, os responsáveis pela comemoração respeitavam a cultura negra e, por isso, incentivaram sua participação nos festejos. Entretanto, apresentavam uma deferência que não condizia com a realidade do cotidiano, dizendo que consideravam uma honra servirem uma alimentação abundante aos negros.

O que se percebe é que os festeiros ao aceitarem a participação dos negros nos festejos reafirmavam o seu poder econômico, pois quanto maior o número de negros no Congado, e estes reconhecidos como trabalhadores de determinado fazendeiro, maior era a projeção política do mesmo na região. Outra tática utilizada era o da comilança, pois que os festeiros ao demonstrarem fartura, reafirmavam seu desprendimento financeiro podendo bancar as refeições coletivas oferecidas à população, incluindo nela os negros. Era de praxe os fazendeiros matarem vacas, porcos e aves para os banquetes coletivos, ofertar latas de doces, tachos de arroz, tutu de feijão, almôndegas, carnes em 
postas guardadas na gordura e distribuídas com fartura aos festantes.

O cotidiano festivo evidenciado pela historiadora Maria das Dores Campos, procura transmitir um pretenso apaziguamento entre negros e brancos, como se este fosse despido de interesses e, muitas vezes visto como positivo, pois, segundo ela, o tratamento despendido aos negros durante os dias de festa pelos fazendeiros era o mesmo atribuído a qualquer pessoa da sociedade.

Talvez fosse possível generalizar que o apoio dado aos negros devotos do Santíssimo Rosário, nas comemorações em Catalão-GO, não se diferenciava dos demais ocorridos pelo Brasil, pois nada mais era do que mascaramento da exploração e maus tratos impostos a eles negros. Como fruto das táticas de projeção social dos fazendeiros não representava, em seu conjunto, a aceitação da cultura do negro. Como e nem tampouco se consolidava num incentivo meramente devocional, como procura transmitir a história local.

A rotina vivenciada pelo negro, no início dos anos de 1900 pelo interior do país, não diferenciava muito dos tempos da escravidão, pois era de muito trabalho, pouca comida e grande humilhação. Esse quadro se revertia momentaneamente em época de festa, pois, como vimos pelo exemplo de Catalão, nesses dias a fartura alimentícia apregoava a imagem de amabilidade dos fazendeiros.

Relacionando a história da escravização negra no Brasil com a realidade descrita pelos historiadores da cidade no que diz respeito ao tratamento despendido aos negros, percebe-se que a fartura dos dias festivos em Catalão era o prenúncio de momentos de muita fome e exploração, pois passada a comemoração eles retornariam a uma intensa jornada, arcando com o ônus da ruptura momentânea com o mundo do trabalho. O que ficava evidente desde então é que a realização de uma grande celebração em louvor a Santa, movida por muita festa, fartura e reza, funcionava como mecanismo de manutenção do poder político e ostentação da riqueza para os fazendeiros que assumiam o papel de festeiros. A maioria concorria ao cargo disputando prestígio social.

Nesse sentido, mascaravam-se os interesses pessoais escamoteados pelo festar e pelo rezar. A comemoração nada mais era do que a vitrine para a ostentação do poder e do prestigio político desses fazendeiros, já que:

Nestes dias de festas os "sinhôs e as sinhás" tinham considerações especiais para com seus pretos empregados nas fazendas que ainda conservavam o hábito e costume da escravidão recentemente extinta. Muitos usavam roupas, jóias e adereços caros de seus patrões. A festa se tornara um multicolorido espetáculo ao som do batido monótono e dolente das caixas que mais pareciam lamentos dos corações oprimidos e injustiçados. Nos pulos, requebros e danças, recordando a África distante, na agitação desordenada de seus corpos suados, no som pungente de suas vozes, dizendo 
palavras esparsas que lembram um culto africano já distante e deturpado, vemos uma raça oprimida e sofrida. Seu canto tem muito de angústia. É um choro que grita contra as algemas da escravidão e do preconceito racial. ${ }^{24}$

Desse modo, ao negro era oferecida a possibilidade de irromper o cotidiano e festejar seus ancestrais, esse festar representava não simplesmente momentos de alegria ou liberdade temporária. Era a expressão latente dos lamentos pela escravidão impregnada na alma dos negros, restando-lhes apenas lastimar a perda de parentes, as saudades, as dores e a humilhação às quais eram submetidos rotineiramente. Todavia, por trás dessa observação a autora induz a acreditar que a abolição foi um marco, uma ruptura e que a angústia do canto e do ritual se referia ao passado e não à exploração e violência da desigualdade social também vigente no presente do qual ela fala.

$\mathrm{O}$ incentivo à festa por parte das camadas mais abastadas da sociedade era estratégia principal na manutenção das pretensões políticas e sociais, vendendo a imagem de pessoas preocupadas com a vida religiosa dos negros. Entretanto, esses eventos carregaram consigo grande carga de intencionalidade, conforme pode ser notado nas descrições de Campos, que nos dá pistas de que a realização se transformava ano a ano numa disputa entre as famílias tradicionais em comandar a Festa, pois sendo palco de maior visibilidade local, os grandes fazendeiros se faziam vistos e até mascaravam as diferenças e as divergências políticas, em prol da manutenção e da disputa pelo poder local. Ela descreve, detalhadamente, os anos de 1905/1917, enfatizando Catalão nesse período e os condicionantes para pensar as pretensões políticas e sociais que levaram muitos fazendeiros a assumirem a festa como benfeitoria sua.

No início desse século um dos homens de maior prestígio em Catalão foi o Coronel Alfredo Paranhos, neto do senador Antônio da Silva Paranhos, filho de Emília Paranhos e José Felipe da Silveira, casado com D. Jacinta Porto Paranhos, também neta do mesmo senador, filha de D. Josefina Paranhos e Antônio Porto. Este casal não teve filhos. Nos primeiros anos deste século XX, foi ele um dos homens de maior prestígio em Catalão. Faleceu em 1917 por um derrame cerebral, na cidade de Estrela do Sul onde fora tratar com especialista do coração. D. Jacinta Paranhos, conhecida como D. Jacintinha, faleceu mais ou menos em 1954 [...]. Em seu poder existia uma liteira, que pertenceu aos seus avós, isto é, ao Senador Paranhos. Em 1908 houve uma revolução no Estado de Goiás sendo que Eugênio Jardim tomou as rédeas do governo do Dr. José Leopoldo de Bulhões, que exerceu o cargo de Ministro da Fazenda no governo do presidente Afonso Pena. Este 
acontecimento refletiu em Catalão da seguinte maneira:

Alfredo Paranhos que era o homem de maior prestígio político perdeu o apoio do governo, sendo nomeado Intendente Municipal Cristiano Victor Rodrigues, filho de Chico Manco e pai de emérito médico falecido há pouco no Rio de Janeiro - o Dr. Francisco Victor Rodrigues. Também a família Aires que era correligionária da facção política do Capitão Carlos de Andrade, teve renovado seu prestígio político na pessoa de José Maria Aires Silva, irmão do coronel Pedro Aires da Silva, cuja irmandade já nos referimos. As famílias Aires e Victor Rodrigues tinham prestígio, mas o chefe que mandava e tudo resolvia era Elizeu da Cunha que tomara parte na morte do Senador Paranhos. Ele próprio contava eufórico que fora seu tiro certeiro que derrubara o grande senador. Elizeu da Cunha esteve na capital em Vila Boa de Goiás tomando parte ativa na luta para depor o presidente José Leopoldo de Bulhões. Regressando a Catalão, teve a proteção do governo para ser absolvido no processo de morte do senador Antônio da Silva Paranhos.[...] Nesta época é que o coronel José Netto Carneiro, o mais velho filho do casal João de Cerqueira Netto (grifo nosso) e Henriqueta Cristina Netto assumiu a direção do partido político "papo roxo" até então liderado pela família Paranhos. Ao lado dele como mentor intelectual estava o grande e talentoso advogado Randolfo Campos. ${ }^{25}$

Percebe-se, pelos nomes elencados, a preocupação da historiadora em registrá-los como representantes natos da sociedade local, as pessoas de maior prestígio e as que ocupavam sempre os cargos de importância na política em Goiás. Muitos deles oriundos das famílias incentivadoras da comemoração ao Rosário no município, endossando a premissa de que a festa nesse momento cumpria o papel a ela delegado de vitrine social para famílias de posse da cidade.

Nesse caminho controverso, é pertinente que os saberes dos grupos sociais não são meros resquícios de outras tradições culturais ou colcha de retalho mal alinhavada. Esses saberes estão integrados a múltiplos valores e sentidos, cuja recriação só é percebida se encaixada na diversidade da cultura popular. Assim a Festa do Congado, nos depoimentos dos congadeiros, representa muito mais do que simplesmente uma comemoração ou uma rememoração de um passado distante, que evoca os seus reis negros e que se materializa, momentaneamente, no tempo presente, através dos rituais contidos nessas festividades.

Nessa perspectiva, a história é:

A construção das possibilidades, sem ela sucumbimos. 
A presença de desejo move a inquietude transparente de cada dúvida. Ela é o ar da vida e dos sonhos [...] O nosso cais que contempla mares nunca antes navegados, com uma sofreguidão às vezes tediosa, ou com uma ansiedade incontrolável e assustadora. [...] Viver a vida sem contá-la é um silêncio vazio, nossa morte. Por isso as narrativas são importantes e decisivas. ${ }^{26}$

Portanto, a história da festa do Rosário de Catalão-GO, ao longo desses anos tem sido recriada propiciando o desvelar de muitas histórias. A maioria perdida pelos vãos da memória. Histórias escritas por muitas vozes - sejam elas definidoras da multiplicidade étnico-cultural ou das simbologias envolvendo a prática do Congado e do hibridismo em torno da devoção a Nossa Senhora do Rosário, ou ainda, por meio de formas e gestos condutores de narrativas inseridas num universo mítico em que a prática festiva ancestral, a fé, a devoção e a festa atribuem novos contornos para as comemorações. Ou também para referendar histórias, reafirmar memórias e interesses de determinados grupos sociais e políticos locais, mas também para se fazer pensar o social, o cultural, o religiosos e suas muitas intencionalidades recriadas e reafirmadas por diverssas narrativas, já que ao narrar, os sujeitos "contam apenas parte do que viu, ouviu ou leu, pois a memória é seletiva, retém apenas os fatos que foram envoltos nos sentimentos". ${ }^{27}$

\section{Notas de Fim}

1 LIMA, V. B. de. Os Caminhos da Urbanização/Mineração em Goiás: O Estudo de Catalão (1970-2000). 2003. Dissertação (Mestrado em Geografia) Universidade Federal de Uberlândia, 2003.

2 SAINT-HILAIRE, A. de, Viagem à Província de Goiás, Belo Horizonte, Itatiaia/EDUSP, 1975

3 BRANDÃO, C. R. A Festa do Santo Preto. Goiânia: UFGO, 1985.

4 PESAVENTO, S. J. Sensibilidades no tempo, tempo das sensibilidades. In: Nuevo Mundo, Mundos Nuevos, $\mathrm{n}^{\circ}$ 4, 2004, disponível em www.ehess.fr/cerma/Revue. Acesso dia 20 de novembro de 2007, p.14.

5 SANTOS, M. P. dos. O Campo (re)inventado: transformações da cultura popular rural no Sudeste Goiano (1950-1990). 2001. Dissertação (Mestrado em História) - Universidade Federal de Uberlândia, 2001, p. 39-40.

6 RAMOS, C. Catalão: Poesias, lendas, histórias. Goiânia: Líder, 1978.

RAMOS, C. Catalão de ontem e de hoje (curiosos fragmentos de nossa História). Catalão: Distribuidora Kalil, 1984.

7 CATALÃO, Goiás. Lei no ${ }^{\circ} 46$ de 03 de outubro de 1973

8 BOLLE, W. Fisiognomia da metrópole moderna: Representação da História em Walter 
Benjamin. São Paulo: Edusp, 2000, p. 272.

9 FLORES, M. B. R. Carrosséis urbanos: da racionalidade moderna ao pluralismo temático ( ou territorialidades contemporâneas). In: REVISTA BRASILEIRA DE HISTÓRIA, vol. 27, $\mathrm{n}^{\circ}$ 53, São Paulo: ANPUH, 2007. p. 267-296.

10 AMADO, J.; FERREIRA, M. de M. Usos e abusos da história oral. 3.ed., Rio de Janeiro: FGV, 2000.

11 BOLLE, W. 2000, p. 335.

12 CERTEAU, M. de. A Invenção do cotidiano - Artes do Fazer. Tomo 1 e 2, 6 ed., Petrópolis: Vozes, 2001, p. 264.

13 ZALUAR, A. O crime e o diabo na terra de Deus. In: Sagrado e profano - X! Retratos de um Brasil de fim de Século. Rio de Janeiro: Agir, 1994. p.115-136.

14 CASCUDO, C. Dicionário do Folclore Brasileiro. São Paulo: Ediouro, Coleção Terra Brasilis, 2000.

15 MORAES FILHO, M. Festas e Tradições Populares do Brasil. Belo Horizonte: Itatiaia/ São Paulo: USP, 1987.

16 BASTIDE, R. As Religiões Africanas no Brasil. 3 ed. , São Paulo: Pioneira.,1989, p. 64.

17 PEREIRA, E. de A. Rosário de muitas fés . In: Revista de Filosofia e Teologia do Instituto Arquidiocesano Santo Antonio. Vol. 04, nº. 16, 1998.

18 ABREU, M. Cultura Popular: um conceito e várias histórias. In: ABREU, M.; SHOIET, R. (orgs). Ensino de História: conceitos, temáticas e metodologia. Rio de Janeiro: Faperj/ Casa da Palavra, 2003. p.83-102.

19 PRIORI, M. Del. Festas e Utopias no Brasil Colonial. São Paulo: Brasiliense, 1994, p. 98.

20 SOUZA, M. de M. e. Reis Negros no Brasil Escravista - História da Festa de Coroação de Rei Congo. Belo Horizonte: Humanitas/UFMG, 2002.

21 VAINFAS, R; SOUZA, Juliana B. de. Brasil de todos os santos. Rio de Janeiro: Zahar editores, 2000.

22 GAETA, Maria Aparecida Junqueira Veiga. A Cultura clerical e a folia popular. Revista Brasileira de História., São Paulo, v. 17, n. 34, 1997, p.07. Disponível em: <http://www. scielo.br/scielo.php>. Acesso: 13 outubro de 2007.

23 CAMPOS, 1979, p.118

24 CAMPOS, 1979, p. 118-119

25 CAMPOS, 1979, p. 107-108.

26 REZENDE, A. P. As seduções do efêmero e a construção da história: as múltiplas estações da solidão e os círculos do tempo. In: ERTZOGUE, M H. \& PARENTE, T. G. História e Sensibilidade. Brasília: Paralelo 15, 2006. p.35-56.

27 COSTA, C. B. da. Memórias Compartilhadas: contadores de história. . Contar história, fazer História - história, cultura e memória. Brasília: Paralelo 15, 2001. p. 73-84.

\section{Artigo recebido em maio de 2017. Aceito em julho de 2017.}

